DOI: https://doi.org/10.3126/njdrs.v16i0.31534

\title{
Effectiveness of Poverty Alleviation Provisions in Nepal with Reference to Periodic Plans
}

\author{
Khom Raj Kharel, PhD \\ Associate Professor at Tribhuvan University, Saraswati Multiple Campus \\ Email for correspondence: kharelkhom@yahoo.com
}

\begin{abstract}
This study seeks to build a better understanding of the poverty alleviation progress in Nepal and to provide an affordable set of strategic options to the government of Nepal for reducing poverty. Despite significant improvements in economic and social indicators over the past four decades, the study shows that poverty is still widespread in Nepal. The study shows that there is significant progress in poverty alleviation in Nepal. The study indicates that poverty incidence has increased over the past 3 decades in Nepal, a period in which Nepal received substantial development assistance. Poverty is the main factor of declining the quality of living standard of Nepalese people. The objective of the government is to attain prosperity of people. The present study attempts to observe the effectiveness of poverty alleviation trends of Nepal on the basis of different plans. Furthermore, my findings emphasize on the effective measures of poverty alleviation. My argument is that Nepal needs to pay more attention for generating employment opportunities of the nation by increasing investment and modernization in agriculture.
\end{abstract}

Key words: Poverty alleviation, programs, plan review, descriptive statistics

\section{Introduction}

Poverty is the condition of having insufficient income. This means people do not have minimum income for fulfilling the basic needs. In its most extreme form, poverty is a lack of basic human needs, such as nutritious food, clothing, housing, clean water, and health services. Most people agree that poverty is a multidimensional concept, but there is no general agreement about what constitutes the various dimensions. Income is often considered an essential dimension, yet it does not capture enough of the poverty concept. Poverty can be defined in a number of ways. The World Bank (1990) has defined poverty as "the inability to attain a minimal standard of living". Poverty shows the situation of scarcity of a person who is struggling for the basic needs and due to this, education and medicine are beyond her/his capacity. However, there is no generally accepted definition of poverty, except, may be, in the very basic sense of freedom from acute hunger. It is basically a subjective concept. According to National Planning Commission (1993), "A state of economic, social and psychological deprivation occurring among people of countries lacking sufficient ownership, control or access to resource to maintain the minimum standard of living". This implies that poverty is a state, which is more than low income. Poverty shows the situation of scarcity of a person who is struggling for the basic needs and due to this, education and medicine are beyond her/his capacity.In this broader concept, poverty may stem from a lack of education, mentality of personal defeatism based on poor self-esteem, social discrimination and luck of opportunity for culture factors.

Nepalese Journal of Development and Rural Studies, Volume 16, 2019 
The problem of poverty is as old as human history, or so, it was concerned. There is no unanimity among the analysts with regard to the definition of poverty and its indicators. Sometimes, it is defined in terms of lack of means in relation to needs, and the poor are identified as those who cannot satisfy their minimum needs. The UN and ILO experts have generally defined poverty in terms of lack of fulfillment of 'basic human needs'. The basic human needs which they have identified are nutrition, shelter, health, education, leisure, security and surplus income (Drewonski \& Scott, 1966). In the early stage of the development of capitalist, mass of the working population lived in generalized poverty (Altimer, 1982). The existing of massive poverty has been well known as an object problem of this era for all countries but particularly in the developing countries. In most of the developing countries, poverty has for centuries, been the lot of the largest part of the population. The perceptions of poverty and underdevelopment, focused in a single fatalistic diagnosis throughout the colonial era.

Amartya Sen (1981) has considered biological approach in defining poverty. According to him, "Poverty is not just a matter of being relatively poorer than others in the society, but of not having some basic opportunities of material well-being; the failure to have certain minimum 'capabilities'. The criteria of minimum capabilities are 'absolute' not in the sense that they must not vary from society to society, or over time, but people with deprivation are judged absolutely and nor simply in comparison with the deprivations of others in that society. If a person is seen as poor because he is unable to satisfy his hunger, then this diagnosis of poverty cannot be altered merely by the fact that others too may also be hungry. As the problem of poverty is concerned, it has multidimensional characteristics. In general unemployment, underemployment and high-income inequalities are found to be major causes of poverty. In the context of Nepal, low levels of capital formation, small land holding, low income, low productivity, increasing expenditure, unemployment outside agriculture, disguised unemployment in agriculture sector and low level of technological advancement in agriculture, high population growth, illiteracy, lack of resources and slow pace of economic growth are also the factors of poverty.

\section{Foundational Work: Empirical Review}

Poverty alleviation has become the essential goal of the development process. Poverty is the most challenging factor in developing countries. Today, not only economists, but scientists also concentrate their technology in favor of human welfare; but the economic development is highly affected from poverty. So the economic development today has been a challenge to eradicate poverty, reducing income inequality and creating employment. Hence, poverty problem is one of the major problems in the world but it is a serious, challenging and burningissues in the developing countries. It has attracted the attention of many researchers, writers and economists. Many of the works on poverty alleviation have been done in African as well as South Asian countries. But poverty in Nepal has been well recognized since the first five year plan (1956-61 AD), the first research on poverty in Nepal shown that there was minimal compared with India and Bangladesh. However, in economists do not show keen interest to Nepal on this issue.

Since the early 1950s, economic upliftment of the poor countries has become an issue of the world concern. Many national and international agencies are found to spend a huge fund on poverty alleviation. Many international organizations and advanced countries are found to be highly devoted to study on poverty alleviation. Nepal is one of the poorest countries in the world. Most economic and social indicators confirm a high incidence of poverty. Economists have conducted many studies in this 
field. The reliable review of the literature is done in this study.

The survey on employment, income distribution and consumption pattern in Nepal was the first official attempts of defining and quantity the level of poverty in Nepal by Nepal Planning Commission (NPC) in 1978. The minimum subsistence level of income and expenditure were used for derivation of the poverty line. An income level of NRs. 2 per capita per day at 1976/77 prices was taken as a minimum subsistence level of income by 605 grams of cereals and 60 grams of pulses to meet the average calorie 2,256 as suggested by Food and Agriculture Organization. Thus, cut off level was based on the expenditure required to buy food giving average daily intake of 2,256 calories and value of the lowest actual daily intake actual daily consumption of other basic necessities.

Hamilton (1968), in his book discussed the meaning of poverty. He also examines income and income distribution and level of standard living. For this purpose he has used Lorenz's curve with secondary data sources. He highlights poverty problem. Finally, the discussion on the question to existence of poverty can be eliminated in the society. He strongly emphasized that the causes of poverty may be inequality to the size of distributions.

'Poverty and famines' written by Amartya Sen who was awarded (1998's) Novel Price in economics. The author shows vivid picture of seriousness of poverty problem and causes of famines in Asian and African countries. He has attempted to discuss on the controversy of measures such as life expectancy etc. He has collected information from various countries, which are able to reduce poverty, and a detail examination of some countries has been performed. He has summarized some causes enhancing the poverty in indicated countries.

\section{Review of Periodic Plans}

Before 1950-51, Nepal was one of the most isolated countries of the world, cut off from effective contact with modern influences, which in varying degree were transforming the economic life of most other nations. In the absence of any substantial compensation economic development, lowlevel poverty became the lot of large proportion of our citizens (First Plan, 1956-61).

At the time the Second Plan prepared, knowledge of economic conditions in Nepal was still extremely limited. Second Plan gave priority to activities which would the base for more comprehensive future plans. Emphasis was given to the collection of data on economic conditions organizational reform and improvement, and the development of the economic infrastructure rather than poverty alleviation (Second Plan, 1962-65).

In the Third Plan (1965-70), increase of public welfare was co-terminus with a higher level of economic development which, in turn, results in increased production. In order to end economic exploitation, suitable changes in the system and organization of both distribution and exchange should accompany increases in production. Since the dangers of exploitation and undue economic pressure was great in poverty stricken society. Since low productivity was the root cause of poverty, in order to create a society free from exploitation and increase production to maximum extent.

Due to lack of necessary data, it was not possible to calculate the actual rate of growth of Gross Domestic Product during the Fourth plan period. However, on the basis of the data that was available during the drafting of the Fourth Plan, the proposed investment and projects to be completed during the Plan period were likely to generate an increase in GDP of 4 percent per annum during the Plan period (Fourth Plan, 1970-75). It was most essential that the rate of production be speeded up, if 
the problems of poverty, unemployment and under-employment, so widely prevalent in the country, should be solved. There was no emphasis about poverty agenda in the Fifth Plan (1970-75).

The objectives set in the Sixth Plan (1975-80) were long-term ones. They stand as much valid today as they did then. Extensive poverty was the main problem of the economy. The increasing production was the only solution for gradual removal of prevailing poverty from the country. The policy in the Seventh Plan (1980-85) were to make the process of development self-reliant by widening the base of local resource mobilization with the use of increased resources, production and employment oriented programs against the background of existing poverty and backwardness in the villages. The policy of securing aid from friendly countries and international agencies were also continued. The foundation works of the process of progressive' development by eliminating the adverse situation in the economic, social and environmental areas in different parts of the country. The main objective of all those efforts of development Nepal would be promoted favorable environment.

There has been significantly studied about poverty problems and measures to reduce poverty before the Eighth Plan period (1992-1997). The comprehensive plan with specific objectives had been started from the Eighth Five Year Plan (1992). In that plan, there was a lack of dependable data as regards the magnitude of poverty it was estimated 49 percent of Nepal's total population lived in absolute poverty. The country's development was obviously impossible without the participation of such a huge section of population in the development process. Hence, special efforts would, therefore, be made during the Eighth Plan for poverty alleviation.

Before the beginning of the Ninth Plan (1997-2002), it was estimated that 42 percent of populations live below poverty line. The macro levels of estimates were not provide disaggregated statistical distributions of poverty on geographical basis. Employment was assumed to be the foremost means of transforming economic development into an opportunity to alleviate poverty. Providing employment to poverty-stricken masses could reduce poverty to make economic development efforts more sustainable.

The planners had set the single objective of poverty alleviation in the Tenth Plan (2002-2007). It had estimated to reduce poverty level from 38 percent to 30 percent in the end of the plan. Various programs had been set to alleviate the existing poverty level. Government had tried to attempt broadbased economic growth, development of rural infrastructures, social integration, improvement in human development index, confessional loan facility, supply of manpower, modernization in agriculture sector etc. Providing employment to poverty-stricken masses can reduce poverty to make economic development efforts more sustainable. With a view to extend the access of the poor community to the employment opportunities created by a broad and sustainable economic growth meant for poverty alleviation, it could be essential to increase their competitive capacity through the development and empowerment.

The vision of Eleventh Plan (2007/08-2009/10) was to build a Prosperous, Modern and Just Nepal. With the realization of this envisaged Vision, Nepal could be self-sustaining and free from the absolute poverty level. The gap between the rich and the poor would have been reduced. The main goal of the plan was to lay a foundation for economic and social transformation to build a Prosperous, Modern and Just Nepal. The main objective of that Plan was to generate an experience of a direct feeling of change in the lives of the general public by supporting in the establishment of peace and 
reducing the existing unemployment, poverty and inequality in the country. For the alleviation of the existing poverty in the country, economic activities were created and extended in order to raise their income by making them participatory for the poor and the helpless people.

The long-term vision of the Twelveth Plan (2010/11-2012/13) was to upgrade country from least developed country to developing country by granting prosperity, peace and justice. In this context, population under poverty level would be zero and Nepal would be a prosperous country. It was expected that poverty level would be 21 percent at the end of plan. The objectives of the plan were to create feeling of change of people focusing employment for poverty alleviation.

The long term vision of Thirteenth Plan (2013/14-2015/16) was also to upgrade Nepal from least developed country to developing country until $2022 \mathrm{AD}$. The objective of the plan was to create direct feeling change to the people by decreasing mass economic and human poverty level of the country. The target of the plan was to reduce poverty level up to 18 percent by end of the plan.

The vision of the Fourteenth plan (2016-2019) was to bring down poverty level and attain economic prosperity by extending approach of factors of production and opportunities of income and employment. The objective of the plan was to alleviate absolute poverty by creating bases of prosperity. The target toward poverty alleviation was to bring down poverty level 17 percent. The main strategy of the plan was to increase employment opportunities in productive sectors and the planners had tried to link the relations with economic prosperity and poverty alleviation.

In the preparation of the Fifteenth Five Year Plan (2019), the introduction of federal system of government, political stability, peace and order and good governance have been maintained, active participation of citizens in development campaign has increased, and poverty alleviation is the responsibility of three tiers of government. This is an opportunity for the Government of Nepal to make efforts to formulate and implement periodical plans and all sectoral plans including agriculture, tourism, development and construction to alleviate poverty, including security and other poverty alleviation programs. The vision of the plan is to maintain poverty-free society of all kinds and goal of the plan is to bring the population below the poverty line to 11 percent from 18.7 percent. The determined objectives are: (i) identify the poor and run programs targeted at the poor, (ii) To create skill development and employment targeting the poor and (iii) To establish easy access of the poor to the resources of the state. For achieving targets and objectives of the plan, various strategies are set as: (i) identify poor households through survey and keep updated details, (ii) formulate and implement poverty alleviation plans, programs and projects targeting the identified poor, (iii) conduct employment and self-employment skill development training and education programs, (iv) ensure access of the poor to it by increasing productive employment and opportunities, (v) ensure access of the poor to the means of production by formulating poverty alleviation policy and (vi) ensuring access of the poor to basic necessities and services.

\section{Research Problems and Objectives}

The Constitution of Nepal has adopted a policy of giving priority to the economically deprived in all genders, regions and communities while providing social security and social justice. For the past three decades, poverty alleviation programs have been implemented in Nepal with the priority of development efforts. Since the Tenth Plan period, poverty has been basically divided into three dimensions namely income poverty, human poverty and social deprivation. In the present contests, 
more than fifty poverty alleviation targeted programs are implementing. Poor household identification and identity card distribution programs have moved forward to focus on poverty-targeted programs. To achieve the targeted goal, increase the per capita income of the poor by addressing the multidimensional poverty and reduce the existing economic inequality between geographical, gender and social groups is an interrelated issue as integrated, coordinating role of government, cooperative, community, private and non-government sector and development partners are the issues of poverty alleviation in Nepal.

By studying the fact, most of poverty-oriented programs are more distribution-oriented than capacity development, inability to run programs aimed at absolute poverty, lack of coordination among various agencies related to scattered poverty alleviation programs, low access to agricultural resources, poor access to State resources and use of socio-economic remittances from foreign employment. Similarly, inability to invest in productive sectors, inability to stop intellectual migration and inability to utilize the capacity of manpower to go for foreign employment by creating employment opportunities according to efficiency and capacity are the major issues related to poverty alleviation in Nepal.

- To examine the effectiveness of poverty alleviation provisions with reference to periodic plans and review of the plan policies.

\section{Methodology}

This study is the descriptive and analytical in nature. So the descriptive and analytical research design has been applied. In case of descriptive research design, tables and diagram as well as examples have been presented as necessary. The paper is primarily based on secondary data, which have been collected from plan documents; economic surveys and publication of Poverty Relieve Office, online, publication of Asian Development Bank, World Bank, annual publication of Government of Nepal and published by Ministry of finance. Besides, the researcher has also collected data from the poverty related journal and articles published in national and international forums. The present research study is to analyze based on the data of 1956/57-2019/20 and the analysis is based on descriptive statistics.

\section{Results and Discussions}

For generations, the economy of Nepal has remained virtually static, until 1950-51, when there was a change in regime; we were one of the most isolated countries of the world, cut off from effective contact with modern influences, which in varying degree were transforming the economic life of most other nations. In the absence of any substantial compensation economic development, lowlevel poverty became the lot of large proportion of our citizens. A significant result of the First Plan was the recognition of the conditions required for successful planning and project implementation. It was realized that a plan formulated without detailed knowledge of actual conditions and the development potential of the several was of limited usefulness.

At the time the Second Plan was prepared, knowledge of economic conditions in Nepal was still extremely limited. In the absence of survey and studies of natural recourses, agricultural output national income and other economic variables, existing economic conditions could not be accurately ascertained. Second Plan gave priority to activities which would the base for more comprehensive future plans. The increase of public welfare was co-terminus with a higher level of economic development which, in turn, results in increased production. Since the dangers of exploitation and undue economic pressure were great in poverty stricken society. Since low productivity was the root cause of poverty, in order to create a society free from exploitation and increase production to maximum extent. Due to lack 
of necessary data, it was not possible to calculate the actual rate of growth of gross domestic product during the Fourth Plan period.

It was most essential that the rate of production be speeded up, if the problems of poverty, unemployment and under-employment, so widely prevalent in the country, should be solved. There was no emphasis about poverty agenda in the Fifth Plan. Extensive poverty was the main problem of the economy and the increasing production was the only solution for gradual removal of prevailing poverty from the country. An attempt was made to assess the changes that had been brought about in the process of the implementation of set objectives and policies during the Sixth Plan.

The policy of securing aid from friendly countries and international agencies were also continued. The foundation works of the process of progressive' development by eliminating the adverse situation in the economic, social and environmental areas in different parts of the country. The country's development was obviously impossible without the participation of such a huge section of population in the development process. The situation was such that the households living in the condition of abject poverty and backwardness, both socially and economically, did not either know at all about the services delivered by the government or they were not able to utilize such services even if they knew about them up to the seventh plan. The poverty level decreased 42 percent from 49 percent end of Eighth plan. Programs which were formulated and implemented in the Eighth plan, were relatively well-to-do families may not grab these benefits and the real poor ones could be benefited directly or indirectly. Hence, all the sectoral programs were directed towards poverty alleviation.

The Ninth Plan has set poverty alleviation as its main objective with a determination of bringing down the number of those below poverty line from 42 percent to 32 percent. The Plan also aimed at improving the living standard of the people below poverty line, placing special emphasis on uplifting the living standard of those lacking productive assets and income-generating resources. Based on this reality, the Tenth Plan divided poverty into mainly three categories; income poverty, human poverty and social exclusion. Analyzing all these categories, the overall poverty and human development indices have significantly improved during the past years.

By the end of 11th plan, poverty level decreased 25.4 percent from 31 percent. In that plan, poverty alleviation measures were significantly effective. In the 12th plan, the target of poverty alleviation was not ambitious; it was just reduced poverty level from 25.4 percent to 21 percent, but the result was just 23.8 percent. By the end of 13 th plan, poverty level was 21.6 percent, though the target of the plan was to bring down 18 percent. Similarly, in the initial period of the Fourteenth plan poverty level was 21.6 percent and target of plan was to bring down 17 percent in the end of the plan.

Table 1. Effectiveness of Poverty Alleviation Provisions in the Different Plans

\begin{tabular}{lccc}
\hline Plan Period & Poverty Level & Targets (\%) & Achievement (\%) \\
Eighth Plan (1992-1997) & $49 \%$ & $42 \%$ & $42 \%$ \\
Ninth Plan (1997-2002) & $42 \%$ & $32 \%$ & $38 \%$ \\
Tenth Plan (2002-2007) & $38 \%$ & $30 \%$ & $31 \%$ \\
Eleventh Plan (2007-2010) & $31 \%$ & $24 \%$ & $25.4 \%$ \\
Twelveth Plan (2010-2013) & $25.4 \%$ & $21 \%$ & $23.8 \%$ \\
Thirteenth Plan (2013-2016) & $23.8 \%$ & $18 \%$ & $21.6 \%$ \\
Fourteenth Plan (2016-2019) & $21.6 \%$ & $17 \%$ & $18.7 \%$ \\
Fifteenth Plan (2019-2024) & $18.7 \%$ & $11 \%$ & - \\
\hline
\end{tabular}

(Various Plan Documents)

Nepalese Journal of Development and Rural Studies, Volume 16, 2019 


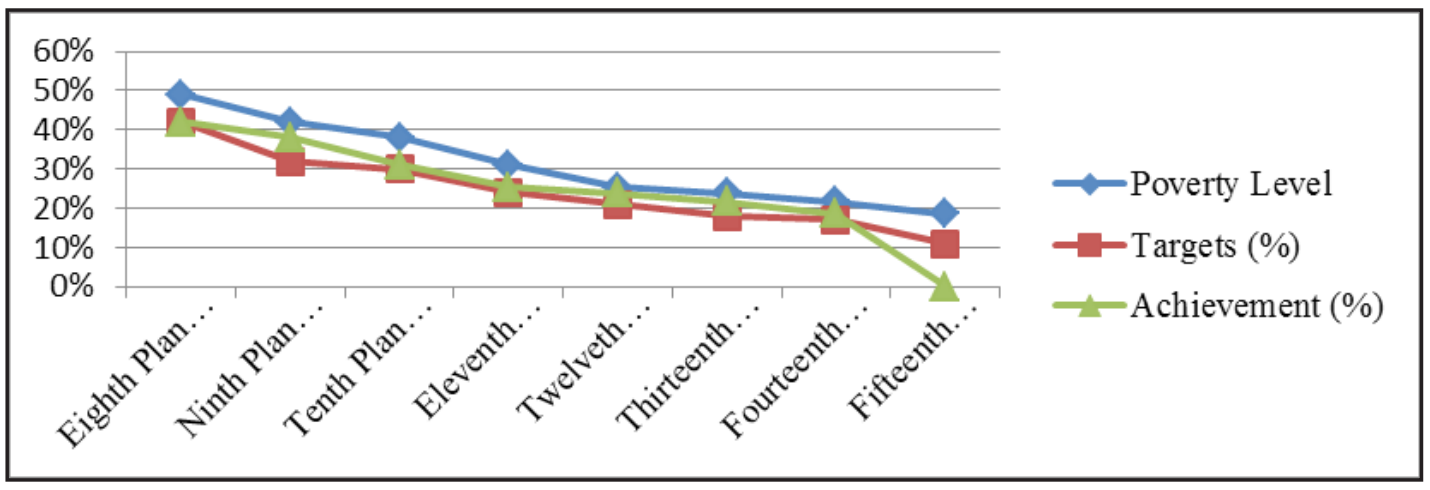

\section{Figure 1. Poverty Level, Targets and Achievement in Plan Periods}

Table 1 and Figure 1 depict the existing poverty level in various plan periods. Before the Eighth plan, the poverty level was systematically analyzed. There were not specific objectives in the plans. Resources were allocated on different sectors without specific targets. After the success of democratic movement in 1990s, Nepal has entered into systematic process for preparing plan periods. In the Eighth plan, target of poverty level met. In the Ninth plan poverty alleviation target was to bring down 32 percent from 42 percent but result was just 38 percent. In the Tenth plan, target of poverty alleviation was to bring down 30 percent from 38 percent. The result was near to the target level i.e. 31 percent. In the 11th plan, target of poverty alleviation was 24 percent from 31 percent and the result was near to target i.e. 25.4 percent. The 12 th plan showed that the poverty alleviation target was to bring 21 percent from 25.4 percent but the poverty level was 23.8 percent in the end of the plan. The poverty level decreased from 23.8 percent to 21.6 percent in the 13 th plan; however target was to bring down 18 percent. The target of poverty alleviation was to bring down 17 percent from 21.6 percent in the 14th plan but the achievement was 18.7 percent. Similarly, the 15th plan has brought with the expectation of reducing absolute poverty from 18.7 percent to 11 percent and the population living in multidimensional poverty from 28.6 percent to 13 percent. The proportion of the upper 10 and lower 40 percent of the population in income would decrease from 1.3 to 1.25 and the property-based Ginni Coefficient will decrease from 0.31 to 0.29 . With the development of the national system of poor identity, identity cards will be distributed to the poor individuals and families of all 77 districts.

\section{The Findings and Conclusion}

Development of country is obviously impossible without the participation of such a huge section of population in the development process. Since the attempts made in the past for poverty alleviation were faulty in principle and weak in implementation, the general public could not benefit from them as expected. Before 1950, Nepal was one of the most isolated countries of the world, cut off from effective contact with modern influences, which in varying degree were transforming the economic life of most other nations. The studies which were been conducted before the Eighth plan for the purpose of quantifying the people living below the poverty line was estimated 40-60 percent of the populations living below the absolute poverty line. Before the Eighth plan, the poverty 
level was not systematically analyzed. There were not specific objectives in the plans. The political changes after1990s, Nepal has entered into systematic process for preparing plan periods. The poverty alleviation target was achieved by the end of Eighth plan. In the Ninth plan poverty alleviation target was to bring down 32 percent from 42 percent but result was just 38 percent. In the tenth plan, target of poverty alleviation was to bring down 30 percent from 38 percent. The result was near to the target level i.e. 31 percent. In the eleventh plan, target of poverty alleviation was 24 percent from 31 percent and the result was near to target i.e.25.4 percent. The Twelveth plan showed that the poverty alleviation target was to bring 21 percent from 25.4 percent but the poverty was 23.8 percent in the end of the plan.

The poverty level decreased from 23.8 percent to 21.6 percent in the Thirteenth plan, however target was 18 percent. Similarly the target of poverty alleviation is to bring down 17 percent from 21.6 percent in the Fourteenth plan. Due to the absence of a competitive atmosphere, attention was not paid towards increasing efficiency, so that satisfactory achievement was not achieved in the economic sector. Since the attempts made in the past for poverty alleviation provisions were faulty in principle and weak in implementation, the general public could not benefit from them as expected. After the effective implementation of plan periods poverty alleviation and human development index have attained significant progress due credit to periodic plan run poverty alleviation programs, social security programs and remittance spent on consumption. Most of millennium development goals have been achieved. Poverty alleviation, being a crosscutting issue of development dimension, is believed to get support if every development activity and project can be linked to the goal of poverty alleviation.

\section{References}

Altimer, O. (1982). The extent of poverty in Latin America (World Bank Stuff Working Paper, Number 522). Washington, D.C., USA: World Bank.

Bajracharya, P. B., \& Bajracharya, B. (1991). Towards integrated strategies for alleviation poverty in Nepal (ARTEP Working Paper). ILO-ARTEP.

Drewonski, J., \& Scott, W. (1966). Level of living index (UNRISD, Report No. 4.). Geneva: Author. Greer, J., \& Thorgecke, E. (1986). 'Ood poverty and consumption, patterns in Kenya, Italy: ILO.

Hamilton, D. (1968). The economics of poverty. New York: Random House.

Islam R., \& Lee L. (1985). Strategies for alleviating poverty in rural Asia. Dhaka: Bangaladesh Institute of Development Studies.

Meier, G. M. (1984). Emerging from poverty. New York: Oxford University Press.

Ministry of Finance (MoF). (2005). Economic survey 2005/06. Singhdurbar, Kathamndu: Government of Nepal. Ministry of Finance (MoF). (2006. Economic survey 2006/07. Singhdurbar, Kathamndu: Government of Nepal. Ministry of Finance (MoF). (2007). Economic survey 2007/08. Singhdurbar, Kathamndu: Government of Nepal. Ministry of Finance (MoF). (2008). Economic survey 2008/09. Singhdurbar, Kathamndu: Government of Nepal. Ministry of Finance (MoF). (2009). Economic survey 2009/10. Singhdurbar, Kathamndu: Government of Nepal. Ministry of Finance (MoF). (2010). Economic survey 2010/11. Singhdurbar, Kathamndu: Government of Nepal. Ministry of Finance (MoF). (2011). Economic survey 2011/12. Singhdurbar, Kathamndu: Government of Nepal. Ministry of Finance (MoF). (2012). Economic survey 2012/13. Singhdurbar, Kathamndu: Government of Nepal. Ministry of Finance (MoF). (2013). Economic survey 2013/14. Singhdurbar, Kathamndu: Government of Nepal. Ministry of Finance (MoF). (2014). Economic survey 2014/15. Singhdurbar, Kathamndu: Government of Nepal. Ministry of Finance (MoF). (2015). Economic survey 2015/16. Singhdurbar, Kathamndu: Government of Nepal. 
Ministry of Finance (MoF). (2016). Economic survey 2016/17.Government of Nepal, Singhdurbar, Kathamndu. National Planning Commission (NPC). (2007). Eleventh three year plan document 2007/08- 2009/10. Singh Durbar, Kathmandu: Government of Nepal.

National Planning Commission (NPC). (2014). Thirteenth three year plan document 2013/14- 2015/16. Singh Durbar, Kathmandu: Government of Nepal.

National Planning Commission (NPC). (1956). First five year plan document 1956-61. Singh Durbar, Kathmandu: Government of Nepal.

National Planning Commission (NPC). (1961). Second three year plan document 1962-65. Singh Durbar, Kathmandu: Government of Nepal.

National Planning Commission (1965). Third five year plan document 1965-70. Singh Durbar, Kathmandu: Government of Nepal

National Planning Commission (NPC). (1970). Fourth five year plan document 1970-75. Singh Durbar, Kathmandu: Government of Nepal.

National Planning Commission (NPC). (1975). Fifth five year plan document 1975-80. Singh Durbar, Kathmandu: Government of Nepal.

National Planning Commission (NPC). (1980). Sixth five year plan document 1980-85. Singh Durbar, Kathmandu: Government of Nepal.

National Planning Commission (NPC). (1985). Seventh five year plan document 1985-90. Singh Durbar, Kathmandu: Government of Nepal.

National Planning Commission (NPC). (1992). Eighth five year plan document 1992-97. Singh Durbar, Kathmandu: Government of Nepal.

National Planning Commission (NPC). (1997). Ninth five year plan document 1997-2002. Singh Durbar, Kathmandu: Government of Nepal.

National Planning Commission (NPC). (2002). Tenth five year plan document 2002-2007. Singh Durbar, Kathmandu: Government of Nepal.

National Planning Commission (NPC). (2010). Twelveth three year plan document 2010/11- 2012/13. Singh Durbar, Kathmandu: Government of Nepal.

National Planning Commission (NPC). (2016). Fourteenth Three Year Plan Document 2016/17201/19. Singh Durbar, Kathmandu: Government of Nepal.

National Planning Commission (NPC). (2019). 'Approach Paper to Fifteenth Five Year Plan Document 2018/19-2023/24'. Singh Durbar, Kathmandu: Government of Nepal.

National Planning Commission (NPC). (1978). A Study on Employment, Income Distribution and Consumption Pattern in Nepal. Summary Report, Vol. IV, and National Planning Commission, Singh Durbar, Kathmandu: Government of Nepal.

National Planning Commission (NPC). (1998).Ninth Plan, Government of Nepal, Singhadurbar, Kathmandu.

National Planning Commission in Association with UNDP/N, WB/N (1993, June 12-24). Poverty, alleviation and human development in Nepal. Preceding of a National Seimar, Kathamndu: Government of Nepal.

Paul, S. (1993). The business community and the poor: Rethinking business strategy and social policy. American Journal of Economics and Sociology, 53. INC, New York: Author. 
Ramashwamy, A., \& Rao, N. V. R. (1985). Poverty is it understood?Inter-India Publications, New Delhi, India.

Seddon, D. (1987). Nepal a state of poverty. New Delhi: Vikas Publishing House Pvt. Ltd.

Sen, A. (1981). Poverty and famines: An essay entitlement and depreciation. ELBS, Italy: Oxford University Press.

Singh, T. (1969). Poverty and social with reappraisal. India: Orient Longman Ltd.

Srinivaran, T. N. (1977). Poverty: Some measurement problems (Reprint Series No. 77). Washington D.C., USA: World Bank.

Thakur, D. S. (1985). Poverty, inequality and unemployment in rural India. New Delhi: B. R. Publishing Corporation.

World Bank (1990). World development report 1991., Washington D.C.: Author.

World Bank (1999).Nepal: Poverty at the turn of twenty first century. Washington D.C.: Author. 